\title{
Kontestasi pendidikan keislaman dan pendidikan umum: persepsi masyarakat tentang sumber kekuatan mobilitas sosial di kabupaten bone
}

\author{
Nursyirwan $^{\mathrm{a}, 1, *}$ \\ ${ }^{a}$ IAIN Bone, Jl. HOS Cokroaminoto, Kab. Bone, Indonesia \\ ${ }^{1}$ nursyirwan@gmail.com* \\ * Korespondensi Penulis
}

Article history

Received June 26, 2020

Revised June 26, 2020

Accepted June 27, 2020

Available Online June 30, 2020

Keywords

Pendidikan keislaman

Pendidikan umum

Persepsi masyarakat

Kekuatan mobilitas
This study examines community perceptions about the ability of Islamic educational institutions and graduate competencies in driving social change vertically in Bone Regency, South Sulawesi. Islamic education is considered powerless in encouraging progress and giving graduates a future. This descriptive qualitative study found a different fact where the misperception about the ability of Islamic education was widespread. Observations and interviews show that religious education institutions have been actively involved in providing policy perspectives in the regions and Islamic education graduates have proven to play an active role not only in the religious field but also in various fields of community and government life. The ability of graduates of Islamic educational institutions even outperformed graduates of non-religious educational institutions because religious graduates have competence in the religious and general fields as well. The results of this study suggest the need for popularization of Islamic educational institutions in the community and intensification of communication with the community so that the existence and progress of Islamic education institutions can be represented according to their position and role in society.

Penelitian ini mengkaji persepsi masyarakat tentang kemampuan lembaga pendidikan keislaman dan kompetensi lulusan dalam mendorong perubahan sosial secara vertikal di Kabupaten Bone, Sulawesi Selatan. Pendidikan keislaman dianggap tidak berdaya dalam mendorong kemajuan dan memberi masa depan pada lulusan. Penelitian yang bersifat kualitatif deskriptif ini menemukan fakta yang berbeda di mana mispersepsi tentang kemampuan pendidikan keislaman terjadi secara meluas. Hasil pengamatan dan wawancara memperlihatkan bahwa lembaga pendidikan keagamaan telah terlibat secara aktif dalam memberikan perspektif kebijakan di daerah dan lulusan pendidikan keislaman terbukti berperan aktif tidak hanya dalam bidang keagamaan tetapi juga dalam berbagai bidang kehidupan masyarakat dan pemerintahan. Kemampuan lulusan lembaga pendidikan keislaman bahkan mengungguli lulusan lembaga pendidikan non-keagamaan karena lulusan keagamaan memiliki kompetensi dalam bidang keagamaan dan umum sekaligus. Hasil penelitian ini menyarankan perlunya popularisasi lembaga pendidikan keislaman di dalam masyarakat dan intensifikasi komunikasi dengan masyarakat agar keberadaan dan kiprah lembaga pendidikan keislaman dapat direpresentasikan sesuai dengan posisi dan peran dalam masyarakat.

This is an open access article under the CC-BY-SA license.

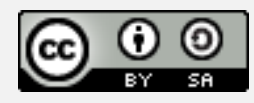




\section{Pendahuluan}

Ketidakpercayaan masyarakat terhadap kemampuan lembaga pendidikan keagamaan dalam menjamin masa depan merupakan fenomena yang sangat memprihatinkan. Hal ini dapat dilihat dari animo masyarakat dalam memasukkan anaknya pada lembaga pendidikan umum masih jauh lebih tinggi dibandingkan dengan anak yang masuk pada lembaga pendidikan keagamaan (Mujiburrahman, et al., 2019). Pada masyarakat Bone, Sulawesi Selatan, kontestasi antara pendidikan keislaman dengan pendidikan umum tampak dengan jelas. Data Dinas Pendidikan Kabupaten Bone menunjukkan ada sekitar 380.001 anak yang masuk pada pendidikan Umum pada tiga Tahun Pelajaran, 2016/2017, 2017/2018, dan 2018/2019 (http://dapo.dikdasmen.kemdikbud.go.id/pd/1/190000). Sementara itu, anak yang masuk pendidikan madrasah dan pesantren hanya 88.282 orang (Dokumen Seksi Pendidikan Madrasah dan Seksi PD Pontren, Kementerian Agama Kabupaten Bone). Menurut Imam Suprayogo, madrasah selalu tertinggal bilamana dibandingkan dengan sekolah umum, prestasi hasil belajar para siswanya rendah dan gurunya tidak berkualitas. Lembaga pendidikan Agama Islam dikelola hanya dengan manajemen seadanya (Suprayogo, 2007).

Sejauh ini studi tentang lembaga pendidikan Islam di Indonesia memiliki tiga kecenderungan. Pertama, studi yang melihat lembaga pendidikan Islam dari proses belajar mengajar yang berlangsung di dalam kelas, termasuk dalam perbandingan dengan model pembelajaran pada lembaga pendidikan non-agama (Ismail et al., 2013; Yamada et al., 2015; Maksymenko \& Tranfaglia, 2015). Kedua, studi yang cenderung melihat pendidikan keislaman pada kurikulum yang diajarkan, khususnya mengkaji penerapan kurikulum tradisional agama (teologi) dan kurikulum nasional yang diatur dalam Kurikulum Nasional 2013 (Hamdhaidari et al., 2008; Kuran, 2018; Muluk et al., 2019; Yusuf dan Sterkens, 2015). Ketiga, studi yang melihat kinerja kelembagaan pendidikan keislaman, dengan fokus pada penguatan kelembagaan, termasuk Sumber Daya Manusia dan infrastruktur kelembagaan (Shah, 2006; Yusuf dan Sterkens, 2016).

Dari ketiga kecenderungan di atas, sangat sedikit perhatian diberikan pada isu relevansi lembaga pendidikan agama Islam terhadap persoalan sosial, khususnya kemampuan lembaga pendidikan keislaman dalam memberi landasan bagi mobilitas sosial masyarakatnya. Hakikat pendidikan adalah menjawab langsung kebutuhan masyarakat atau lebih spesifik lagi lembaga pendidikan dibentuk sebagai jawaban atas persoalan-persoalan yang dihadapi masyarakat. Pada saat yang sama, lembaga pendidikan Islam juga tidak lepas dari persoalan menantang untuk dicarikan jalan keluarnya. Lembaga pendidikan Islam selain menghadapi persoalan internal, juga menghadapi kompetisi dengan pendidikan umum. Oleh karena itu, penelitian yang mengambil fokus tentang bagaimana peran lembaga pendidikan Islam dalam meningkatkan mobilitas sosial di Kabupaten Bone menjadi sangat signifikan untuk dilakukan.

Pendidikan adalah salah satu kunci yang mendorong penciptaan sekularisasi. Tujuan dari pendidikan untuk meningkatkan keterampilan kognitif, mengembangkan sikap yang lebih kritis terhadap otoritas, dan menempatkan peningkatan penekanan pada otonomi pribadi dan penilaian individu yang akibatnya menghasilkan religiusitas yang lebih rendah. Oleh karena itu dibutuhkan pendidikan agama sebagai upaya peningkatan religiusitas individu (Kuenzi, 2018: 255) Di banyak negara, pendidikan agama dipandang sebagai instrumen dalam menangani multikulturalisme dan pluralisasi dalam pendidikan publik. pendidikan agama adalah wajib di sekolah dasar Finlandia (715 tahun) dan pendidikan menengah atas. model saat ini untuk pendidikan agama dan etika, yang antara lain, memberikan siswa hak untuk pendidikan agama sesuai dengan tradisi mereka sendiri, tetapi dari dasar non-konfensional berbeda dari pendekatan yang diadopsi di negara-negara nordik lainnya (Ubani et al., 2019: 10)

Di Inggris dan Wales, setidaknya sampai akhir 1950-an, pendidikan agama, moral dan kewarganegaraan dipandang sangat terkait. Pendidikan agama disamakan dengan pendidikan Kristen, suatu bentuk pengajaran yang memiliki tujuan moral dan sipil. Dalam suasana pembaruan moral dan sosial setelah Perang Dunia Kedua, Pemerintah Inggris melihat pengajaran agama yang ditafsirkan sebagai pengajaran Kristen 'nondenominasional' sebagai dasar moralitas dan kewarganegaraan, dan sebagai prinsip yang memadukan semua pendidikan. Pada 1960-an, persamaan virtual pendidikan agama, pendidikan moral, dan kewarganegaraan yang baik ini ditantang oleh sekularisasi yang semakin nyata. Proses ini tercermin dalam tren sosial, tetapi meresapi wacana akademik, termasuk teologi kontemporer dan filosofi agama (Jackson, 2013: 5) 
belum terdapat perubahan hukum terhadap subjek pendidikan agama semenjak tahun 1988 dengan subjek sebelumnya instruksi agama. Akan tetapi karena kurangnya kurikulum nasional tentang pendidikan agama sehingga banyak sekolah membuat kurikulum pendidikan agama sendiri dan terdapat banyak bukti pada tingkat menengah, nama pendidikan agama diganti dengan alternatif seperti "Beliefs and Values, Religion and Belief anad Religion, Philosophy and Ethics. Ada sejumlah alasan untuk tren ini, secara umum tujuannya adalah agar pendidikan agama bisa tampak lebih inklusif (Bråten \& Everington, 2018: 7-8).

Pendidikan agama menjadi isu sosial yang menarik dikaji. Agama adalah model dan rencana lengkap dan universal yang dapat menjadi pedoman dan petunjuk membimbing manusia dalam semua dimensi budaya, ilmiah, ekonomi dan sosial dan menyiapkan pedoman untuk heidup lebih baik dan lebih maju (Purrostami, 2012). Menyoal isu pendidikan agama agaknya agama berkorelasi dengan beberapa aspek kehidupan. Pada lintas negara, pendidikan, tingkat religiusitas, tingkat perkembangan ekonomi dan tingkat demokrasi berkorelasi. Negara-negara yang lebih berpendidikan rata-rata cenderung kurang religius. Mereka juga memiliki demokrasi yang lebih kuat serta pendapatan per kapita yang lebih tinggi (Mocan \& Pogorelova, 2017) sehingga pendidikan agama menjadi aspek krusial yang perlu dipelajari. Konsep pengalihan epistemik memegang implikasi penting bagi pedagogik pendidikan agama yang bertujuan mengatasi doktrin agama dan pluralisme agama dalam pendidikan agama (Zembylas, dkk, 2019).

Dari banyak penelitian ditemukan berbagai kasus pendidikan agama yan kurang mendapat perhatian komunitas agama karena penyediaan layanan pendidikan sebagian besar berasal dari kecendrungan untuk fokus pada sistem pendidikan publik yang dianggap mengimbangi diskusi global mengenai pendidikan. Kemiskinan menjadi masalah utama bagi terciptanya pendidikan swasta hanya memiliki sedikit relevansi dengan pendidikan agama. Kurangnya keterlibatan dengan aktor-aktor keagamaan juga dapat menerminkan perbedaan pendekatan, agenda, dan prioritas diantara disiplin dan komunitas swasta dengan pendidikan berbasis agama (Marshall, 2018), kebijakan pemerintah juga sangat mempengaruhi keberadaan dan minat orang tua memasukkan anaknya ke sekolah berbasis agama(Méon \& Tojerow 2018) dengan kapasitas birokrasi yang lemah untuk mengelola program dan kebijakan, kapasitas terbatas untuk menyediakan layanan berkualitas, dan bersaing dengan kebutuhan dan kepentingan dalam mengejar kebijakan pendidikan (Niño, 2016).

Pendidikan adalah fenomena sosial yang merupakan bagian dari realitas sosial. Masyarakat menjadi bagian dari fitur-fitur pendidikan yang turut menentukan dan berkontribusi pada apa yang ingin dicapai melalui praktik pendidikan. Pendidikan merupakan sebuah proses pengaruh yang dilakukan oleh generasi dewasa pada mereka yang belum siap untuk kehidupan sosial dengan tujuan utama untuk membangkitkan dan mengembangkan pengetahuan seseorang tentang keadaan fisik, intelektual, dan moral yang dituntut oleh masyarakat. Pendidikan sebagai pengorganisasian atau rekontruksi pengalaman yang konstan yang memiliki peran sosial untuk membiasakan orang-orang yang dipercayai kepadanya dengan realitas fisik kehidupan dan memberi praktik untuk menjadi anggota masyarakat yang baik. Keadaan masyarakat berbanding lurus dengan bagaiman kondisi dan tingkat pendidikan yang diperoleh (Komonen, 2015).

Karena pentingnya pendidikan ada istilah lifelong learning bagi masyarakat pembelajar yang melakukan pembelajaran seumur hidup dari kesadaran individu dalam rangka memperkuat masyarakat yang telah mengembangkan cara-cara terorganisir untuk meningkatkan tingkat pendidikan kolektifnya, memperoleh pengetahuan baru, dan menerapkan pengetahuan baru. Masyarakat itu sendiri menjadi entitas pembelajaran yang terus mengembangkan kemampuannya untuk menciptakan alat baru untuk perbaikan kolektif. dalam masyarakat pembelajar, teknik untuk peningkatan intelektual pekerja di semua tingkatan, yang dikembangkan oleh organisasi untuk keuntungan mereka sendiri, pada saat yang sama, bermanfaat bagi komunitas yang lebih luas (Sandmann et al, 2016), sedangkan alasan menempuh pendidikan agama karena menghasilkan perubahan pada kognitif (pengetahuan dan asumsi nilai-nilai, prinsip-prinsip dan norma-norma agama), afektif-motivasi (mendukung manifestasi keyakinan agama dan dukungan motivasi diperlukan untuk mematuhi norma-norma) dan tingkat perilaku (memperoleh keterampilan khusus untuk perilaku keagamaan) dalam masyarakat (Manea, 2014).

Mobilitas sosial adalah proses individu berpindah dari satu lapisan masyarakat ke lapisan lainnya, biasanya standar pelapisan sosial dilihat dari latar belakang pendidikannya, ekonomi, 
pekerjaan dan latar belakang keluarga (Houle, 2017), dalam pendidikan mobilitas memiliki kontribusi yang sangat besar dalam memobilitas pendapatan negara karena pendidikan adalah pondasi ilmu pengetahuan yang penting bagi kuantitas dan kualitas tenaga kerja (Guo et al,2019). Banyak penelitian yang menyatakan bahwa kecerdasan kognitif adalah indikator utama keberhasilan dan pencapaian seseorang. Tingkat pendidikan seseorang menentukan pekerjaan yang akan dicapai nantinya. Akan tetapi, tidak semua bidang dalam kemampuan kognitif memprediksi pencapaian pendidikan dan sosial ekonomi yang setara. Kemampuan kognitif dalam menghitung (pelajaran matematika) tidak memiliki efek yang lebih besar pada pancapaian kerja (Anni \& Mõttus, 2019) dari pada kemampuan verbal seperti pentingnya pendidikan bahasa Inggris bagi sekolah menegah atas dan perguruan tinggi (Jayadeva, 2019:2).

Pendidikan adalah bagian dari masyarakat yang menjadi seperangkat institusi kunci dari hubungan-hubungan sosial dan hubungan antar individu. Pendidikan sebagai institusi yang secara historis berfungsi sebagai mesin mobilitas sosial seseorang, bahkan dalam sejarah perjuangan Afrika di Amerika melawan masyarakat yang rasis, seperti Cina yang memperbaiki sistem pendidikan dengan komiteman untuk membuat mayoritas kelas menengah Tiongkok dan pendidikan tinggi kemudian disamakan dengan perbedaan budaya yang telah menjadi penentu utama status sosial pada masyarakat Cina, dengan adanya perbaikan sistem pendidikan di Cina mengalami peningkatan kualitas pendidikan yang sangat baik pada masyarakat kelas menegah (Marginson, 2017: 6), karena sekolah telah memainkan peran dalam penciptaan gerakaan untuk keadilan umum. Pendidikan memainkan peran sosial dalam pembentukan identitas karena rasa cinta, emosi dan cara pandang dibangun oleh adanya pendidikan di sekolah (Apple, 2012).

Tulisan ini mencoba merespons kekurangan dari studi yang ada dengan menitikberatkan pada persepsi masyarakat Bone terhadap kemampuan pendidikan keislaman dalam mendorong mobilitas sosial. Sejalan dengan ini, tiga pertanyaan dapat diajukan, yaitu: (1) bagaimana keberadaan pendidikan keagamaan di Bone; (2) bagaimana konsepsi dan persepsi masyarakat tentang pendidikan keislaman; dan (3) penilaian masyarakat tentang kemampuan lembaga pendidikan keislaman dalam mendorong terjadinya mobilitas sosial.

Tulisan ini berlandaskan pada asumsi bahwa pendidikan keislaman tidak dapat dilepaskan dari kebutuhan praktis dan kontekstual yang ada dalam lingkungan masyarakat. Pada sebuah negara dengan komposisi masyarakat yang sangat religius, dan peran agama sangat dominan, baik dalam ranah publik maupun privat (Hefner, 2011; van-Bruinessen, 2008; Pohl, 2009; Yusuf, dan Sterkens, 2015) lembaga pendidikan keislaman seharusnya menjadi pendorong utama atas terjadinya mobilitas sosial. Lembaga pendidikan Islam harus membekali peserta didik dengan penguasaan keterampilan hidup (life skill) sehingga mereka dapat menjadi individu yang mandiri dan siap bersaing dalam perkembangan karir. Begitu pula, lembaga pendidikan keislaman sekarang ini harus dapat mengembangkan kurikulum yang kontekstual, responsif, dan adaptif dengan kebutuhan masyarakat.

\section{Metode}

\subsection{Jenis Penelitian}

Penelitian ini merupakan jenis penelitian deskriptif kualitatif untuk menelusuri persepsi masyarakat mengenai lembaga pendidikan keagamaan sebagai pendorong mobilitas sosial di Kabupaten Bone. Informan atau responden yang dipilih adalah beberapa tokoh dan anggota masyarakat dimintai informasi secara suka rela yang terdiri atas kelompok yang mewakili unsur birokrasi, kepolisian, akademisi, pegawai, pengusaha, pendidik, dan masyarakat umum. Teknik pemilihan informan dengan mengirimkan kuesioner melalui aplikasi WhatsApp kepada beberapa unsur masyarakat. Dari beberapa nama yang dikirim secara proporsional ada tigabelas yang bersedia membalas WhatsApp tersebut. Meskipun jumlahnya relatif sedikit, namun beberapa unsur tersebut telah mencukupi.

\subsection{Teknik Pengumpulan Data}

Pengumpulan data dilakukan dengan tiga cara. Pertama, dengan melakukan observasi awal untuk mendapatkan informasi awal mengenai konsepsi dan persepsi masyarakat Bone mengenai lembaga pendidikan sebagai pendorong mobilitas sosial. Kedua, dengan menyebarkan kuesioner yang berisi pertanyaan terkait fakta empiris mengenai pendidikan umum dibandingkan pendidikan keagamaan dan penilaian masyarakat tentang kemampuan lembaga pendidikan dalam mendorong 
mobilitas sosial. Ketiga, dengan menggunakan dokumen untuk mendapatkan deskripsi mengenai sejarah awal perkembangan lembaga pendidikan keagamaan di Kabupaten Bone.

\subsection{Teknik Analisis Data}

Analisis data dalam penelitian ini dilakukan dengan tiga tahapan, yaitu reduksi data, display data, dan penarikan simpulan. Tahapan reduksi adalah tahapan mengumpulkan data, mengklasifikasi, mengelompokkan, tahapan kedua adalah display data yaitu menyajikan dan mempresentasikan data yang didapatkan secara deskriptif argumentatif dan dilengkapi dengan tabel yang terkait. Tahapan selanjutnya adalah membuat simpulan untuk menggambarkan tiga hal. Pertama, penarikan simpulan mengenai hasil utama dari penelitian ini yang hanya dapat diketahui dengan cara penelitian. Kedua, penarikan simpulan terkait penggunaan teori dan konsep-konsep yang digunakan. Ketiga, simpulan yang terkait pemanfaatan metode yang digunakan untuk menjelaskan hubungan antara peran lembaga endidikan keagamaan dengan pendorong mobilitas sosial dalam masyarakat.

\section{Hasil dan Pembahasan}

\subsection{Keberadaan pendidikan keagamaan di Bone}

Pertumbuhan lembaga pendidikan keislaman di Bone berawal dari terbentuknya secara formal pendidikan Madrasah Amiriyah Islamiyah pada Tahun 1933 di Bone oleh persatuan ulama dan pemuka rakyat. Keberadaan Madrasah Amiriyah Islamiyah di Bone menjadi unik karena pendiriannya dipelopori oleh Raja Bone ke-32, Andi Mappayukki Sultan Ibrahi, bersama dengan salah satu ulama yang berasal dari Madinah, yaitu Syekh Mahmud Abdul Jawwad al-Madani. Cikal bakal ide pendirian lembaga tersebut adalah pertemuan para ulama se-Sulawesi Selatan yang menghasilkan kesepakatan mengenai pengembangan pendidikan keislaman melalui institusi pendidikan madrasah. Perpaduan antara pemerintah dan ulama dalam merintis lembaga pendidikan Islam era tersebut sungguh memiliki nuansa tersendiri. Di sini dapat digambarkan peran pemerintah, dalam hal ini Raja Bone ke-32 mempunyai kepedulian dalam bidang pendidikan, bukan hanya pada pendidikan umum, tetapi juga pada pendidikan Islam. Gambaran peserta didik pada lembaga pendidikan keagamaan di Kabupaten Bone dalam tiga tahun terakhir dapat dilihat pada Tabel 1.

Tabel 1. Jumlah Peserta Didik Lembaga Pendidikan Keagamaan Kab. Bone

\begin{tabular}{cccc}
\hline Lembaga Pendidikan & $\mathbf{2 0 1 6 / 2 0 1 7}$ & $\mathbf{2 0 1 7 / 2 0 1 8}$ & $\mathbf{2 0 1 8 / 2 0 1 9}$ \\
\hline Madrasah Ibtidaiyah & 8.238 & 8.238 & 8.385 \\
Madrasah Tsanawiyyah & 9.940 & 9.950 & 11.074 \\
Madrasah Aliyah & 6.787 & 6.989 & 6.262 \\
Pondok Pesantren & 4.082 & 4.153 & 4.184 \\
Jumlah & 29.047 & 29.330 & 29.905
\end{tabular}

Pendidikan keislaman di Bone dapat dikategorikan pada tiga tipologi pendidikan, yaitu pendidikan informal, formal, dan nonformal. Dalam beberapa keluarga masih menerapkan pendidikan keislaman berupa pendidikan membaca Al-Qur'an dan melatih dan membiasakan putraputri untuk shalat lima waktu, termasuk di antaranya melaksanakan shalat berjamaah, membiasakan anak untuk berpuasa, baik berpuasa penuh atau puasa setengah hari. Dalam pendidikan formal, di Bone terdapat lembaga pendidikan Madrasah Ibtidaiyah, Tsanawiyah, dan Aliyah, dan Pendidikan Tinggi Keislaman, pondok pesantren. Di samping itu, terdapat pendidikan SDIT. Di lembaga pendidikan umum, juga diajarkan matapelajaran Pendidikan Agama Islam dan Budi pekerti hanya saja dengan alokasi waktu yang tidak memadai. Pada pendidikan nonformal, berkembang TK/TPA, PIAUD, Madrasah Diniyah, Majelis Ta'lim yang digerakkan oleh penyuluh Keagamaan Islam, pengajian khalaqah di beberapa masjid setiap selesai shalat Magrib sampai shalat Isya, pendidikan tahfiz dan rumah tahfiz untuk mengembleng calon penghafal Al-Qur'an, pembinaan melalui organisasi remaja masjid.

Peserta didik di sekolah-sekolah Islam, terdiri atas peserta didik dari kalangan yang beragam. Akhir-akhir ini, ada kecenderungan peserta didik di sekolah keislaman dari kalangan perkotaan lebih mendominasi dibandingkan dengan anak dari luar kota. Kecenderungan lainnya adalah peserta didik 
dari kalangan pejabat eksekutif, legislatif, pengusaha, birokrasi, politisi, akademisi, dan profesional. Kecenderungan ini, menunjukkan bahwa pamor pendidikan keislaman mengalami penguatan yang signifikan dibandingkan beberapa dekade sebelumnya, yaitu peserta didik didominasi oleh kalangan luar kota, pedalaman, petani. Dulu, pendidikan Islam seakan-akan milik kalangan bawah, sementara pendidikan umum banyak digemari oleh kalangan atas.

\subsection{Konsepsi dan persepsi masyarakat tentang pendidikan keislaman}

Masyarakat Bone mengkonsepsikan pendidikan umum sebagai fondasi yang tidak dapat diabaikan, sementara itu pengetahuan keagamaan kurang mendapat perhatian (Syamsidar, 43 Tahun). Pengetahuan agama perlu ditambah alokasi waktunya pada pendidikan umum, sedangkan pada pendidikan agama pengetahuan umum perlu juga diperkuat agar dapat membentuk karakter yang dibutuhkan dalam dunia kerja. Pendidikan keagamaan memiliki poin plus (Nurhayati, 40 Tahun). Ada anggota masyarakat yang berkeyakinan bahwa lembaga pendidikan keagamaan dapat saling menggantikan (Kasim, 42 Tahun; Nurhayati, 40 Tahun). Kedudukan pendidikan umum dengan pendidikan keagamaan tidak dapat saling menggantikan (Djalante, 59 Tahun; Eryani, 46 Tahun; Murni, 48 Tahun; Syamsidar, 43 Tahun), tetapi perannya dapat saling melengkapi (Sulaiman, 50 Tahun). Pendidikan umum mengisi aspek pengetahuan yang dibutuhkan dalam life skill dan di sisi lain pendidikan keagamaan bukan hanya untuk kebutuhan secara lahiriah, melainkan untuk pemenuhan kebutuhan batiniyah. Kurikulum lembaga pendidikan keagamaan seharusnya dapat dipadukan (Husain, 47 Tahun) dengan memformulasikan, baik dari segi tujuan, materi, maupun metode pembelajaran. Kenyataan lainnya adalah visi misi pendidikan umum, justru mengadopsi sistem pendidikan keislaman (Wardana, Tahun).

Masyarakat menyadari bahwa anak perlu didorong untuk mendapatkan pendidikan keagamaan di lembaga pendidikan Islam agar memiliki pondasi keimanan, akhlak yang mulia. Pada dasarnya, alasan orang tua cukup beragam, baik karena keinginan kuat untuk memberi bekal dasar berupa akidah/keimanan kepada anak-anaknya (Djalante, 59 Tahun) maupun bekal akhlak, moral, dan etika (Ampa, 52 Tahun; Eryani, 46 Tahun; Wardana, Tahun) yang berimbas pada kekhawatiran anak-anak terjangkit penyakit sosial (Patmawati, 40 Tahun). Ada pula yang karena kesibukan sehingga mempercayakan kepada lembaga pendidikan keislaman yang diyakini dapat menggantikan peran orang tua untuk mendidik anak (Sulaiman, 50 Tahun). Setidaknya dalam lembaga pendidikan keagamaan, peserta didik bukan hanya dibekali pendidikan keagamaan, melainkan juga bekal pengetahun umum (Rahman, 50 Tahun; Nurhayati, 40 Tahun). Kecenderungan masyarakat yang menganggap bahwa masa depan anak di pendidikan keagamaan dapat lebih menjanjikan dibandingkan dengan pendidikan umum (Ampa, 52 Tahun; Djalante, 59 Tahun; Sulaiman, 50 Tahun; Kasim, 42 Tahun; Patmawati, 40 Tahun). Akan tetapi, semua itu tidak berjalan otomatis (Husain, 47 Tahun) dan sangat tergantung pada potensi, minat, bakat, dan keinginan anak (Murni, 48 Tahun). Sekarang ini, lembaga pendidikan, baik umum maupun keagamaan saling bersaing untuk menunjukkan jati dirinya (Syamsidar, 43 Tahun; Patmawati, 40 tahun; Nurhayati, 40 Tahun; Wardana, Tahun). Dominan masyarakat mengakui bahwa posisi penting masing banyak didapatkan oleh lulusan lembaga pendidikan umum karena mereka menyiapkan jauh hari potensi dan kompetensi yang dibutuhkan masyarakat (Ampa, 52 Tahun; Djalante, 59 Tahun; Eryani, 46 Tahun; Rahman, 50 Tahun; Murni, 48 Tahun; Syamsidar, 43 Tahun; Kasim, 42 Tahun; Nurhayati, 40 Tahun), setidaknya (Zulkifli, 47 Tahun) mengungkapkan optimisnya bahwa lembaga pendidikan keagamaan berbenah diri sehingga dapat memperoleh kedudukan yang penting dalam instansi pemerintahan. Sulaiman menyatakan bahwa posisi atau kedudukan dalam instansi pemerintahan sangat terkait dengan adanya kesepakatan (Sulaiman, 50 Tahun) tergantung pada kebutuhan lembaga atau nstansi itu (Husain, 47 Tahun).

Dalam dunia kerja, kesesuaian latar belakang pendidikan keagamaan dengan tupoksi masingmasing dapat diamati dari penyataan masyarakat yang dominan menyatakan sesuai, baik karena didukung oleh lembaga pendidikan yang berbasis kompetensi dan lapangan kerja (Djalante, 59 Tahun) selain itu lulusan pendidikan keagamaan dapat menyesuaikan diri (Eryani, 46 Tahun), berkinerja yang baik (Husain, 47 Tahun), dan bekerja sesuai dengan keahlian (Murni, 48 Tahun). Dapat diakomodir (Patmawati, 40 Tahun). Meskipun demikian, masih saja ada yang tidak sesuai antara latar belakang pendidikannya, tetapi karena ada faktor kekerabatan (Syamsidar, 43 Tahun). Dari sisi daya saing antara lulusan pada lembaga pendidikan dapat menunjukkan prestasi yang tidak mengecewakan, karena mereka didukung oleh pendidikan dan pelatihan (Djalante, 59 Tahun). meskipun disadari bahwa prestasi yang didapatkan bukan semata-mata hasil dari lembaga 
pendidikan keagamaan yang pernah mengemblengnya. Dari aspek keterampilan dan kompetensi lulusan lembaga pendidikan keislaman rata-rata memiliki komitmen dan kinerja yang baik (Husain, 47 Tahun). Lulusan pendidikan keagamaan mempunyai daya saing bahkan kadang-kadang mampu menyaingi kompetensi lulusan pendidikan umum (Murni, 48 Tahun). Kapolres Bone mengungkapkan bahwa lulusan pendidikan keagamaan mempunyai kelebihan karena dapat berfungsi sebagai penceramah Kamtibmas melalui pendekatan kemasyarakatan (Kasim, 42 Tahun). Dalam beberapa instansi pemerintahan lulusan lembaga pendidikan keagamaan dapat menjadi pemimpin (Zulkifli, 47 Tahun).

\subsection{Kemampuan pendidikan keislaman mobilitas sosial}

Dewasa ini, lembaga pendidikan mempunyai daya jual yang cukup menggembirakan dan dengan modal tersebut dapat menciptakan mobilitas sosial yang signifikan, kalaupun ada kasus mereka yang putus sekolah atau tidak mendapatkan pendidikan tinggi dapat tetap eksis di masyarakat (Syamsidar, 43 Tahun). Pendidikan keagamaan bukan satu-satunya jalur untuk meningkatkan status sosial seseorang (Husain, 47 Tahun). Banyak yang sukses bukan hanya karena faktor lembaga pendidikan, tetapi kemauan dan keuletan (Ampa, 52 Tahun). Dari hasil penelitian, umumnya masyarakat Bone menyakini bahwa pendidikan merupakan sarana untuk dapat meningkatkan derajat dan harkat seseorang menjadi lebih baik.

Meskipun peran lembaga-lembaga keagamaan bukan satu-satunya faktor penyebabnya seseorang mendapatkan posisi yang strategis dan menentukan dalam lingkungan masyarakat, namun masyarakat menyadari bahwa peran lembaga pendidikan keagamaan tidak dapat dikesampingkan. Menurut Syamsidar (43 tahun), seorang imam masjid dalam masyarakat sangat dihormati. Hal ini memberikan indikator bahwa posisi terhormat dalam masyarakat dapat berbentuk posisi sebagai pejabat publik di luar bidang keagamaan. Bahkan kedudukan dan fungsi keagamaan yang kadangkadang dianggap sebagai kedudukan kelas dua dalam masyarakat, telah bermetamorfosis menjadi sebuah kedudukan yang dihargai dan urgen dalam masyarakat. Sejalan dengan ini, Asisten II Pemda Bone, Bapak Asriadi, mengungkapkan bahwa lulusan pendidikan keislaman sangat diperhitungkan dalam menentukan kebijakan publik. Kapolres Bone pun berkeyakinan bahwa mereka yang berpendidikan Islam yang baik, dapat meningkatkan kinerjanya dan pada akhirnya lulusan dari lembaga pendidikan keagamaan dapat meneruskan kebijakan publik dengan akhlak Islam yang dia miliki. Hal senada diungkapkan salah seorang tokoh masyarakat, Zulkifli (47 Tahun), bahwa fatwa para lulusan lembaga pendidikan Islam mempunyai andil besar dalam penentuan kebijakan publik karena fatwanya.

Kenyataan yang tidak dapat dipungkiri adalah masih seringnya didengarkan ungkapan-ungkapan miring dalam pembicaraan masyarakat terkait dengan potensi lembaga pendidikan keagamaan, meskipun kecenderungan tersebut sudah mulai berkurang sedikit demi sedikit seiring dengan semakin menguatnya posisi lembaga pendidikan keagamaan di tengah-tengah masyarakat. Ungkapan sinis yang masih sering muncul adalah suatu asumsi bahwa lembaga pendidikan keagamaan hanya dapat melahirkan orang-orang yang mampu di bidang keagamaan, hanya mampu khutbah, ceramah, baca Al-Qur'an dengan fasih, menjadi imam shalat, baca doa (Djalante, 59 Tahun; Rahman, 50 Tahun; Murni 48 Tahun; Patmawati, 40 Tahun; dan Zulkifli, 47 Tahun). Yang tidak kalah penting adalah pengetahuan keagaman yang tidak berbanding lurus dengan pengamalan nilai-nilai keislaman dalam kehidupan sehari-hari, baik dalam bentuk tutur kata, menyamaikan pendapat, berpakaian islami, dan perilaku (Ampa, 52 Tahun; Eryani, 46 Tahun; Murni, 48 Tahun, Syamsidar, 43 Tahun; Nurhayati, 40 Tahun).

\subsection{Akar sejarah pembedaan tegas antara pendidikan keislaman dengan pendidikan umum}

Keberadaan lembaga pendidikan Madrasah Amiriyah Islamiyah bagi masyarakat Bone yang religius merupakan suatu hal yang sangat monumental. Prakarsa dan pembangunannya merupakan kolaborasi antara kekuasaan di bawah kendali raja Bone dengan ulama. Perpaduan dua kekuatan besar dalam lingkungan sosial merupakan suatu yang masih sangat langka. Di mana seorang raja mempunyai kepedulian terhadap belum adanya pendidikan formal dalam pendidikan keagamaan. Sementara pendidikan umum hanya dapat dinikmati oleh kalangan masyarakat dengan status sosial yang lebih mapan. 
Dalam lingkungan keluarga, telah banyak mengalami pergeseran nilai-nilai pendidikan keagamaan. Pada era tahun delapan puluhan, pendidikan keluarga memegang peran penting dalam menjaga nilai-nilai keislaman. Lingkungan keluarga menjadi institusi pendidikan keagamaan pertama dan utama. Pendidikan Baca tulis Al-Qur'an masih dominan dilakukan sendiri dalam lingkungan keluarga, sedangkan pendalaman tajwid dan tahsinul qira'ah dilanjutkan oleh guru-guru mengaji yang lebih spesifik di luar lingkungan keluarganya sendiri. Demikian pula dengan, pembiasaan dalam melaksanakan ibadah, seperti shalat dan puasa. Pendidika keluarga mempunyai peran yang sangat urgen, salah satu bentuk keluarga memastikan anak-anaknya melaksanakan shalat lima waktu adalah ketika masuk waktu magrib, maka tidak ada lagi anak-anak yang berkeliaran di luar rumah. Waktu terbaik dalam pembinaan pendidikan karakter bagi anak dalam lingkungan keluarga adalah di malam hari, khususnya antara magrib dan isya. Hampir di semua rumah dapat didengarkan bacaan dan lantunan ayat suci Al-Quran. Dalam hal tatakrama, keluarga mempunyai peran yang tidak kalah pentingnya. Seorang anak dapat menempatkan dirinya sebagai anak yang harus patuh dan berbakti kepada kedua orang tua, menghormati orang lain yang lebih tua dan menghargai yang lebih muda. Pergeseran tipologi pendidikan dari institusi pendidikan informal ke pendidikan formal atau nonformal sedikit demi sedikit ikut mempengaruhi hubungan emosional antara anak dengan lingkungan keluarganya dan pada akhirnya pembelajaran Baca Tulis Al-Quran tidak lagi dilakukan langsung oleh keluarga, tetapi diserahkan ke institusi pendidikan lainnya. Rumah tangga sekarang ini sunyi dari lantunan ayat suci Al-Qur'an, shalat lima waktu di luar kontrol orang tua, dan tatakrama pun tidak lagi menjadi hal yang perlu dijunjung tinggi.

Kecenderungan anak-anak di lingkungan perkotaan, baik dari kalangan keluarga pejabat eksekutif, legislatif, pengusaha, birokrasi, politisi, akademisi, dan profesional memasukkan anaknya untuk menuntut ilmu di lembaga pendidikan keagamaan karena disadari sarana dan prasarana serta fasilitas pendidikan keagamaan sudah semakin baik dan bermutu. Kurikulum pendidikan telah diramu sedemikian rupa sehingga tidak lagi berada pada kelas sosial yang rendah, bahkan beberapa lembaga pendidikan keagamaan justru mengalahkan lembaga pendidikan umum. Demikian pula dengan kompetensi dan profesionalitas para pendidik dan tenaga kependidikan yang semakin mampu bersaing dengan pendidik dai kalangan lembaga pendidikan umum. Di sisi lain hasil pendidikan keagamaan di era sebelumnya yang banyak didominasi oleh kalangan bawah telah membuka mata masyarakat bahwa lembaga pendidikan keagamaan dapat tidak dapat dikesampingkan.

\subsection{Fakta perbedaan kemampuan lulusan pendidikan keislaman dengan pendidikan umum}

Lembaga pendidikan umum dengan lembaga pendidikan keagamaan merupakan institusi pendidikan yang mempunyai peran yang penting dalam kehidupan bermasyarakat. Secara faktual keberadaannya tidak dapat saling menggantikan, tetapi menempati fungsi yang saling melengkapi. Dalam memformulasikan dirinya, lembaga pendidikan umum mengadopsi kelebihan pada pendidikan keagamaan, sedangkan pendidikan keagamaan juga mengadopsi kelebihan pada pendidikan umum. Sejatinya dalam mengadopsi itu, lembaga pendidikan keagamaan dapat lebih mudah dan berpeluang untuk mendapatkan penguatan dibandingkan dengan pendidikan umum. Hal inilah yang menjadi kekuatan pada lembaga pendidikan keagamaan sehingga dapat mendudukkan dirinya pada posisi yang ideal.

Tidak dapat diragukan keberadaan lembaga pendidikan keagamaan menunjukkan perkembangan yang signifikan. Masyarakat menaruh kepercayaan karena bukan hanya mendapatkan pengetahuan keagamaan secara teoretik, melainkan juga mendapatkan pembiasaan-pembiasaan dalam pelaksanaan ibadah ataupun dalam tata perilaku sehari-hari. Apalagi beberapa lembaga pendidikan keagamaan menerapkan sistem boarding school, seperti pesantren, dimana peserta didik tinggal bersama dengan peserta didik lainnya dalam lingkungan pondok pesantren. Dalam lingkungan tersebut, peserta didik tidak hanya mendapatkan pembelajaran secara teoretik dalam kelas klasikal, tetapi mereka juga mendapatkan live skill yang sangat dibutuhkan dalam mengarungi kehiduoan dalam masyarakat kelak. Meskipun di beberapa lembaga pendidikan umum juga mengembangakan sistem pendidikan boarding school, namun sistem pembinaan tidak menfokuskan pada pembinaan akhlak sehingga lembaga pendidikan keagamaan, khususnya pondok pesantren masih unggul dibanding dengan lembaga pendidikan lainnya.

Lembaga pendidikan keagamaan sekarang ini menjadi incaran para orang tua yang akan menyekolahkan anak-anaknya. Para orang tua akan mencari informasi lembaga pendidikan 
keagamaan yang karakter apa yang diinginkan untuk ditempuh. Kadang-kadang harus mengeluarkan biaya yang cukup fantastis untuk menyekolahkan anak-anaknya di jenjang pendidikan menengah yang cenderung lebih mahal dibandingkan dengan biaya pendidikan pada jenjang yang lebih tinggi lainnya. Orang tua bukan hanya mengorbankan biaya, tetapi juga merelakan anak-anaknya menempuh pendidikan di tempat yang jauh dari tempat tinggalnya. Kenyataan ini tentu sangat berbeda kalau orang tua menyekolahkan anak-anaknya di lembaga pendidikan umum.

\subsection{Kontribusi pendidikan keislaman}

Lembaga pendidikan keagamaan, khususnya yang menggunakan sistem boarding school dapat memberi kecakapan hidup yang sulit didapatkan dalam pendidikan yang bersifat klasikal, termasuk lembaga pendidikan keagamaan yang klasikal. Dalam sistem boarding school, anak dibiasakan secara alamiah untuk dapat hidup secara mandiri, disiplin, teratur, kreatif, dan sebagainya. Pola pembinaan seperti ini akan membiasakan peserta didik untuk hidup bersama dalam kemajemukan. Kecakapan hidup ini tidak selamanya hanya mengedepankan kemampuan intelektual semata, bahkan kecerdasan emosional menjadi suatu keniscayaan. Kecerdasan emosional ini hanya dapat tumbuh dan berkembang melalui pembiasaan dalam kehidupan sehari-hari.

Kemampuan seseorang dalam mendorong mobilitas sosial tidak hanya ditentukan oleh satu faktor, tetapi pendidikan merupakan salah satu pintu mobilitas sosial yang terbuka. Setiap orang dapat menggunakan pintu lembaga pendidikan ini sebagai sarana efektif dan efisien untuk mengubah status sosialnya dalam masyarakat. Apalagi didukung dengan keterampilan hidup yang pernah didapatkan dalam lembaga pendidikan keagamaan yang berbasis boarding school. Kemandirian, kedisiplinan, keuletan, kreativitas seseorang yang dibentuk sejak dini akan menjadi modal untuk dapat bersaing dan mendorong dirinya untuk meningkatkan derajat sosialnya. Jadi, lembaga pendidikan keagamaan, khususnya pendidikan pada pondok pesantren merupakan satu jalur yang efektif dan efisen serta bersifat terbuka yang siapa saja dapat memperolehnya.

Pada dasarnya, sikap sinis yang seringnya didengarkan dalam pembicaraan masyarakat terkait dengan potensi lembaga pendidikan keagamaan merupakan sesuatu yang yang positif untuk dilakukan evaluasi terhadap lembaga pendidikan keagamaan. Jika lulusan lembaga pendidikan keagamaan hanya dapat melahirkan orang-orang yang mampu di bidang keagamaan, hanya mampu khutbah, ceramah, baca Al-Qur'an dengan fasih, menjadi imam shalat, baca doa bukanlah sesuatu yang sifatnya celaan, justru menjadi indikator yang harus dikuasai oleh seorang lulusan lembaga pendidikan keagamaan. Ungkapan sinis atas tingkah laku seseorang tidak sesuai antara pengetahuan keagamaan dengan pengamalan nilai-nilai keislaman dalam kehidupan sehari-hari, seharusnya harus menjadi perhatian pengelola lembaga pendidikan keagamaan karena seharusnya pengetahuan kognitif yang teoretis tidak bernilai jika tidak diterapkan dalam kehidupan nyata. Ketidakpercayaan masyarakat kepada lembaga pendidikan keislaman berawal dari yang dilihat dan dirasakan oleh masyarakat sehingga harus diatasi dengan melakukan yang seharusnya dilakukan dan mengamalkan yang seharusnya diamalkan.

\section{Simpulan}

Ternyata telah terjadi misrepresentasi masyarakat atas kinerja lembaga pendidikan keislaman di Kabupaten Bone. Sikap sinis masyarakat terhadap kemampuan lembaga pendidikan Islam dan kompetensi lulusan pendidikan Islam tidak merupakan citra lama yang direproduksi dalam wacana publik. Hasil penelitian memperlihatkan bahwa lembaga pendidikan keagamaan mampu mengubah derajat sosial seorang. Dalam banyak hal peran lembaga pendidikan agama Islam perlu direlevansikan dengan persoalan sosial, khususnya mobilitas sosial, agar misrepresentasi masyarakat terhadap peran lembaga pendidikan tersebut dapat dikonsepsikan secara positif. Pada akhirnya, tingkat kepercayaan dan penerimaan masyarakat terhadap lembaga dan lulusan dapat meningkat sehingga membuka ruang-ruang publik yang seluas-luasnya.

Konsepsi masyarakat tentang peran lembaga pendidikan keagamaan yang berbentuk penilaian terhadap kinerja lembaga pendidikan keagamaan di Kabupaten Bone sangat membantu merumuskan sistem kelembagaan pendidikan yang meningkatkan mobilitas sosial melalui jalur institusi pendidikan. Masyarakat mempersepsikan bahwa lembaga pendidikan memberi solusi atas kebutuhan masyarakat. Peran agama dalam tata kehidupan bermasyarakat telah menggambarkan dengan jelas kemajuan yang dicapai suatu bangsa. 
Berdasarkan analisis terhadap persepsi masyarakat dapat ditemukan hubungan yang jelas yang menjadi penyebab utama terjadinya ketidakpercayaan masyarakat terhadap kemampuan lembaga pendidikan keagamaan dalam meningkatkan kompetensi dan derajat sosial seseorang dalam lingkungan masyarakatnya, baik dari sisi internal maupun secara eksternal. Lembaga pendidikan keislaman diharapkan dapat bergerak secara aktif untuk menangkal tantangan lembaga pendidikan umum di satu sisi, dan tumbuh suburnya lembaga pendidikan keagamaan di sisi yang lain. Lembaga pendidikan seharusnya secara kontekstual, responsif, dan adaptif memperhatikan kebutuhan masyarakat dan pada akhirnya dapat memicu munculnya ketidakpercayaan terhadap lembaga pendidikan keagamaan.

\section{Daftar Pustaka}

Bråten, O. M. H., \& Everington, J. (2018). Issues in the integration of religious education and worldviews education in an intercultural context. Intercultural Education, 117.doi:10.1080/14675986.2018.153930

Guo, Y., Song, Y., \& Chen, Q. (2019). Impacts of education policies on intergenerational education mobility in China. China Economic Review.doi:10.1016/j.chieco.2019.03.011

Hamdhaidari, S., Agahi, H., \& Papzan, A. (2008). Higher education during the Islamic government of Iran (1979-2004). International Journal of Educational Development, 28(3), 231245.doi:10.1016/j.ijedudev.2006.11.001

Hefner, Robert (2000). Civil Islam: Muslims and democratization in Indonesia.Princeton University Press.

Houle, C. (2017). Social Mobility and Political Instability. Journal of Conflict Resolution, 002200271772343.doi:10.1177/0022002717723434

Ismail, M., Rahim, P. R. M. A., \& Yusoff, M. S. M. (2013). Educational Strategies to Develop Discipline among Students from the Islamic Perspectives. Procedia - Social and Behavioral Sciences, 107, 80-87.doi:10.1016/j.sbspro.2013.12.402

Jackson, R. (2013). Rethinking religious education and plurality: Issues in diversity and pedagogy. Routledge.

Jayadeva, S. (2019). English-Medium: Schooling, Social Mobility, and Inequality in Bangalore, India. Anthropology \& Education Quarterly.doi:10.1111/aeq.12287

Khamis, A., \& Sammons, P. (2007). Investigating educational change: The Aga Khan University Institute for educational development teacher education for school improvement model. International Journal of Educational Development, 27(5), 572580.doi:10.1016/j.ijedudev.2006.12.006

Kimonen, Eija (2015) Education and Society in Comparative Context The Essence of OutdoorOriented Education in the USA and India. SENSE PUBLISHERS ROTTERDAM / BOSTON / TAIPEI

Kuenzi, M. (2018). Education, religious trust, and ethnicity: The case of Senegal. International Journal of Educational Development, 62, 254-263.doi:10.1016/j.ijedudev.2018.05.007

Kuran, T. (2018). Islam and Economic Performance: Historical and Contemporary Links. Journal of Economic Literature, 56(4), 1292-1359. doi:10.1257/jel.20171243

Maksymenko, S., \& Tranfaglia, A. (2015). The impact of professional athlete sponsorship on educational attainment in Western Kenya. International Journal of Educational Development, 41, 97-103.doi:10.1016/j.ijedudev.2015.02.004

Manea, A. D. (2014). Influences of Religious Education on the Formation Moral Consciousness of Students. Procedia - Social and Behavioral Sciences, 149, 518523.doi:10.1016/j.sbspro.2014.08.203

Marginson, S. (2017). Higher education, economic inequality and social mobility: Implications for emerging East Asia. International Journal of Educational Development.doi:10.1016/j.ijedudev.2017.03.002 
Marshall, K. (2018). Global education challenges: Exploring religious dimensions. International Journal of Educational Development, 62, 184-191.doi:10.1016/j.ijedudev.2018.04.005

Méon, P.-G., \& Tojerow, I. (2018). The minority ethic: Rethinking religious denominations, minority status, and educational achievement across the globe. Journal of Comparative Economics.doi:10.1016/j.jce.2018.11.001

Mocan, N \& Pogorelova, L. (2017). Compulsory schooling laws and formation of beliefs: Education, religion and superstition. Journal of Economic Behavior \& Organization 142, 509-539

Muluk, S., Habiburrahim, H., Zulfikar, T., Orrell, J., \& Mujiburrahman, M. (2019). Developing generic skills at an Islamic higher education institution curriculum in Aceh, Indonesia. Higher Education, Skills and Work-Based Learning.doi:10.1108/heswbl-06-2018-0064

Niño-Zarazúa, M. (2016). Aid, education policy, and development. International Journal of Educational Development, 48, 1-8.doi:10.1016/j.ijedudev.2015.12.002

Pohl, Florian (2006). Islamic education and civil society: Reflections on the pesantren tradition in contemporary Indonesia. Comparative Educa-tion Review, 50 (3), 389-409.

Purrostami, H. (2012). The role of religious and ethical teachings in the modern system of education. Procedia - Social and Behavioral Sciences 46, 4775 - 4781.

Sandmann, L. R., Furco, A., \& Adams, K. R. (2016). Building the field of higher education engagement: A 20-year retrospective. Journal of Higher Education Outreach and Engagement, 20(1), 1-14.

Shah, S. (2006). Educational leadership: an Islamic perspective. British Educational Research Journal, 32(3), 363-385.doi:10.1080/01411920600635403

Suprayogo, Imam. 2007. Quo Vadis Madrasah, Gagasan, Aksi dan Solusi Pembangunan Madrasah. Yogyakarta: Hikayat

Ubani, M., Poulter, S., \& Rissanen, I. (2019). Introduction to contextualising dialogue, secularisation and pluralism in Finnish public education. Contextualising dialogue, secularisation and pluralism: Religion in Finnish public education,

Van Bruinessen, Martin (1996). Islamic state or state Islam? Fifty years of state-Islam relations in Indonesia. In Ingrid Wessel (ed.), Indonesien am Ende des 20. Jahrhunderts, (pp. 19-34), Hamburg: Abera.

Yamada, S., Fujikawa, K., \& Pangeni, K. P. (2015). Islanders' educational choice: Determinants of the students' performance in the Cambridge International Certificate Exams in the Republic of Maldives. International Journal of Educational Development, 41, 6069.doi:10.1016/j.ijedudev.2015.01.001

Yusuf, Mohamad, \& Carl Sterkens (2014). Religious education in religiously affiliated schools and the influence of the state and religious commu- nity on school politics. In Volker Küster, \& Robert Setio (eds.), Christian-Muslim relations in Indonesia and the Netherlands (pp. 4771). Leipzig: Evangelische Verlagsanstalt.

Yusuf, M., \&Sterkens, C. (2015).Analysing the State's Laws on Religious Education in Post-New Order Indonesia.Al-Jāmi'ah: Journal of Islamic Studies, 53(1), 105-130. http://dx.doi.org/10.14421/ajis.2015.531.105-130.

Yusuf, Mohamad (2016). Religious Education in Indonesia An empirical study of religious education models in Islamic, Christian and Hindu affiliated schools. Munster: Lit Verlag.

Zembylas, M., Loukaidis, L., Antoniou, M., \& Antoniou, P. (2019). Religious doctrines and critical religious education: teachers' epistemic switching in a confessional setting. British Journal of Religious Education, 41(3), 286-298. DOI: 10.1080/01416200.2018.1484694 